\title{
NUtRACEUTICAL EFFECTS OF MORINGA OLEIFERA, LEAVES, SEED AND EXTRACT ON SIDE EFFECTS OF ISOPROTERENOL INDUCED MYOCARDIAL DAMAGE IN MALE RATS
}

\author{
By \\ Maha,A.El-Mowafy El Maadawy, Ahdab Abdo \\ Nutrition and Food Science Dept., Home Economics Dept, Faculty of \\ Faculty of Design and Home Economic， Specific Education, Zagazig University, \\ Qassim University, Saudi Arabia \\ Egypt
}

Research Gournal Specific Fducation

Faculty of Specific Education

SMansoura University

ISSUE NO. 44, OCTOBER. 2016

مجلة بعوث التربية النوعية - جامعة المنصورة

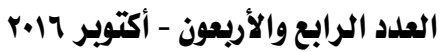


- Nutraceutical effects of Moringa oleifera, leaves, seed and extract on side effects of Isoproterenol 


\title{
Nutraceutical effects of Moringa Oleifera, leaves, Seed and EXTRACT ON SIDE EFFECTS OF ISOPROTERENOL INDUCED MYOCARDIAL Damage In Male RatS
}

\author{
Maha ,A.El-Mowafy ${ }^{*}$ \\ El Maadawy, Ahdab Abdo ${ }^{* *}$
}

\section{Abstract}

The present study evaluated preventive effect of Moringa oleifera leaves, seed powder and water extract of the isoproterenol (ISP)-induced myocardial infarction. Forty adult albino male rats Sprague -Dawley strain weighing $145 \pm 6 \mathrm{~g}$ were classified into five groups, $(8$ rats each) the first group was fed on basal diet only control negative(-ve) group and four rat groups which injected ISP ( $85 \mathrm{mg} / \mathrm{kg}$, s.c.) at an interval of 24 hours. tow day 1 and 2 to induce myocardial infarction .and reclassified into non-treated control positive (+ve) group was fed on basal diet only, and treated groups which were Moringa oleifera leaves, ,seed powder $(500 \mathrm{mg} / \mathrm{kg} \mathrm{b.w})$ and Moringa oleifera water extract $(300 \mathrm{mg} / \mathrm{kg} \mathrm{b} . \mathrm{w})$ in $10 \mathrm{ml}$ of normal saline daily by stomach tube, for 60 days The results revealed that, the control (+ve) group showed a significant decrease in weight gain; food intake, feed efficiency ratio(FER), protein efficiency ratio(PER), serum high density lipoprotein cholesterol (HDLc), superoxide dismutase( SOD) ,catalase (CAT) and glutathione-S-transferase (GST) but a significant increase in serum cholesterol (CHO), triglyceride(TG), low density lipoprotein cholesterol (LDLc), very low density lipoprotein cholesterol (VLDLc), Atherogenic indices $\mathrm{CHO} / \mathrm{HDL}$, amino transferase, (AST,ALT), alkaline phosphates (ALP),Lactatet dehydrogenase(LDH) in heart tissue Lactatet dehydrogenase(LDH),Nitric oxide(NO)and Xanthine oxidase (XO) Compared with control (-ve) group. The Moringa oleifera leaves, seed powder and water extract rat groups showed a significant increase in weight gain; food intake, (FER), (PER), serum (HDLc),( SOD) , (CAT) and

* Nutrition and Food Science Dept., Faculty of Design and Home Economic, Qassim University, Saudi Arabia

Home Economics Dept, Faculty of Specific Education, Zagazig University, Egypt 
- Nutraceutical effects of Moringa oleifera, leaves, seed and extract on side effects of Isoproterenol

(GST).While showing a significant decrease in serum CHO, TG, (LDLc), (VLDLc), CHO/HDL, AST, ALT, ALP, LDH, and Malondialdehyde (MDA) in heart tissue LDH, NO and XO Compared with control (+ ve) group Histopathological examination revealed that, heart of myocardial infarction rat treated with Moringa oleifera leaves, seed powder and Moringa oleifera water extract showed apparent normal heart and nonhistopathological changes These biochemical changes were accompanied with histopathological alterations.It can be concluded that the administration of Moringa oleifera leaves, seed and water extract can lower the side effects of isoproterenol induced myocardial infarction rats and reducing the risk factors for cardiovascular disease such as hyperlipidemia ,leakage of cardiac markers and healthy condition

Key words: Moringa oleifera leaves, seed extract , isoproterenol (ISP), rats

\section{INTRODUCTION}

Despite the advances in the treatment of coronary artery disease, acute myocardial infarction is one of the leading causes of morbidity and mortality worldwide in both men and women Adams( 2002); and Whellan (2005). When myocardial cells are injured or destroyed due to ischemia (deficient oxygen supply or glucose), the cardiac membrane becomes permeable or may rupture which results in leakage of macromolecules from damaged tissue Sasikumar and Shyamala Devi (2000). Among these macromolecules, enzymes are the best markers of tissue damage because of their tissue specificity and catalytic activity. These cellular enzymes are released as a response to $\beta$-adrenergic stimulation Ebenezar et al (2003) or due to the alterations in the integrity and permeability plasma membrane. These alterations may be due to the damage caused by the $\beta$-agonist (ISO) to the sarcolemma. Isoproterenol (ISO) is a synthetic catecholamine and [beta]-adrenergic agonist, which has been found to cause a severe stress in the myocardium, resulting in infarct-like necrosis of the heart muscle. Chagoya et al (1997) Catecholamines rapidly undergo autoxidation, and it has been suggested that the oxidative products of catecholamines are 
responsible for changes in the myocardium. Yates and Dhalla (1975). Lipid peroxide is a causative factor for irreversible damage to the myocardial membrane and thus favors the deposition of myocardial lipids. ISO-induced myocardial necrosis showed alterations in membrane permeability, which bring about the loss of function and integrity of myocardial membranes. Padmanabhan, (2007). Moringa oleifera Lam that belongs to Moringaceae family is commonly known as Drumstick tree that possesses various nutritional and medicinal values attributed to its roots, bark, leaves, flowers, fruits, and seeds are used in the management of obesity and heart disese Kumar et al (2010.).Recently cardiac stimulation and hypocholesterolemic activity from crude extract of Moringa oleifera crude extract was explored Ghasi et al (2000) Therapeutic potential of $M$. oleifera in chronic hyperglycemia and dyslipidemia. Chronic hyperglycemia is an indicator of diabetes mellitus (DM), and chronic dyslipidemia a risk factor for cardiovascular disease (CVD). These metabolic disorders are global epidemics (Yusuf et al.,2001; Wild et al., 2004). The dietary consumption of $M$. oleifera could be advocated in these and other countries as an inexpensive prophylactic strategy against DM and CVD. (Hossain et al., 2007; Aje and Miller, 2009 The safety of an aqueous leaf extract given orally to rats at doses of $400,800,1600$, and $2000 \mathrm{mg} / \mathrm{kg}$ bodyweight was examined the consumption of Moringa. oleifera leaves at doses of up to $2000 \mathrm{mg} / \mathrm{kg}$ were safe. A dose-dependent decrease in body weights of the rats occurred over the 21 days (Adedapo et al., 2009).

\section{MATERIALS AND METHODS}

\section{A - Materials}

1-Isoproterenol hydrochloride was purchased from Sigma Chemical Company St.Louis, MO, USA

2- Moringa oleifera, leaves, seed and extract were purchased from Egyptian Society Moringa National Center for Research in Giza City, Egypt 
- Nutraceutical effects of Moringa oleifera, leaves, seed and extract on side effects of Isoproterenol

\section{3-Experimental animals:}

Forty adult albino male rats Sprague -Dawley strain were purchased from the Agricultural Research Center, Giza, Egypt.The average weight was $145 \pm 6 \mathrm{~g}$. The animals were kept under observation for five days before experiment and fed on standard diet according to NRC, (1995) and water ad-libitum. The standard diet comprised of casein $(200 \mathrm{~g} / \mathrm{kg})$, corn starch $(497 \mathrm{~g} / \mathrm{kg})$, sucrose $(100 \mathrm{~g} / \mathrm{kg})$, cellulose (30 g/kg), corn oil $(50 \mathrm{~g} / \mathrm{kg})$, mineral mixture $(100 \mathrm{~g} / \mathrm{kg})$, vitamins mixture $(20 \mathrm{~g} / \mathrm{kg})$ and DL-methionine $(3 \mathrm{~g} / \mathrm{kg})$.

\section{B- Methods:}

\section{1-Preparation of Isoproterenol hydrochloride (ISO)}

(ISO) was prepared at a concentration of $85 \mathrm{mg} / \mathrm{kg}$ body weight in cold saline. Cardio toxicity was induced by subcutaneous administration of ISO ( $85 \mathrm{mg} / \mathrm{kg}$ body weight) (Goyal et al. 2009).

\section{2-Cardiotoxicity albino rats}

Cardiotoxicity was induced in Wistar albino rats by two subcutaneous injection of freshly prepared solution of Isoproterenol hydrochloride $(85 \mathrm{mg} / \mathrm{kg})$ body weight in cold saline after overnight fasting for $18 \mathrm{~h}$ interval for two days $\mathbf{1}$ and 2 according to (Goyal et al. 2009)

\section{3-Preparation of Moringa oleifera}

\section{- Moringa oleifera leaves powder}

Fresh Moringa oleifera leaves were cut into small pieces, dried at $60^{\circ} \mathrm{C}$ in hot oven and crushed to a fine to obtain moringa oleifera leaves powder and given to rats at dose $500 \mathrm{mg} / \mathrm{kg}$ daily by stomach tube

\section{-Moringa oleifera extract}

$5 \mathrm{~kg}$ of Moringa oleifera plant powder was mixed five times with 5 L hot water the extract was filtered and the filtrate was evaporated to dryness with a rotatory vacuum evaporator at $50^{\circ} \mathrm{C}$ to give $150 \mathrm{~g}$. The Moringa oleifera plant extract was given to rats at dose $300 \mathrm{mg} / \mathrm{kg}$ daily by stomach tube 


\section{- Moringa oleifera seeds powder}

Dried Moringa oleifera seeds were washed with tap water to remove possible potential dust and exposed to air-circulated oven at $40^{\circ} \mathrm{C}$ to complete dryness then grinded to fine powder and given to rats at dose 500 $\mathrm{mg} / \mathrm{kg}$ daily by stomach tube

\section{4- Grouping of rats and experimental design:}

The rats were randomly classified into five groups ( 8 rats each) and fed on the standard diet. The rats classified into control negative (-ve) group and four rat groups which injected ISO $(85 \mathrm{mg} / \mathrm{kg}$ body weight) in cold saline solution and reclassified into untreated control positive (+ve), and treated rat groups which were administration of Moringa oleifera leaves and seed powder $(500 \mathrm{mg} / \mathrm{kg} \mathrm{b.w})$ Moringa oleifera water extract $(300 \mathrm{mg} / \mathrm{kg}$ b.w) in $10 \mathrm{ml}$ of normal saline daily. All treatments were given in stock solution by stomach tube all over the period of the experiment. The study was assigned for 60 day. The rats were subjected daily to physical examination for observation of healthy condition such as external appearance, color of hair, body condition and activity of rats. The food intake was calculated daily and the body weight gain was recorded weekly Feed efficiency ratio and protein efficiency ratio were determined according to the method of Chapman et al., (1950)

\section{5- Collection of blood and heart samples:}

At the end of the experiment period, the rats were anaesthetized by diethyl ether and sacrificed to obtain blood samples of each rat were withdrawn in test tubes The tubes of blood were left for coagulation then centrifuged at $3000 \mathrm{rpm}$ for 15 minutes to obtain serum for each individual sample and then stored at $-20{ }^{\circ} \mathrm{C}$ for some laboratory analyses. Heart of male rats was rapidly removed.

\section{6-Determination of some of serum biochemical parameters:}

Estimation of serum total cholesterol(CHO), triglyceride (TG), high density lipoprotein cholesterol (HDLc), and Low density lipoprotein cholesterol (LDL) were estimated by using the spin react enzymatic kits according to Young (2001), David and Buccolo (1973), Tietz (1976), Lee 
and Nieman (1996) Very low density lipoprotein (VLDL)was calculated VLDL-c $=$ TG/ 5, according Friedewald et al., (1972) Atherogenic indices (CHO/HDL-c) was calculated according to Castelli and levitar, (1977). Serum alanine and aspartate amino transferase (ALT \& AST), alkaline phosphatas (ALP) and Lactatet dehydrogenase (LDH) enzymes activity were performed according to the method of Bergmeyer and Horder (1980), Kind and King (1954), and Caband and Wroblewski (1958)respectively. The heart of each were immediately removed and homogenized in cold $\mathrm{KCl}$ solution $(1.5 \%)$ to give a $10 \%$ homogenate and used for measuring Lactatet dehydrogenase (LDH), Nitric oxide (NO) and Xanthine oxidase (XO) were estimated in the heart tissues according to Caband and Wroblewski (1958), Williams(1984) and Bergmever (1974)), respectively. Superoxide dismutase (SOD), catalase(CAT),glutathione-Stransferase(GST)enzymes and malodialdehyde (MDA) were estimated in the Serum according to Misra and Fridovich (1972) Cohen et al., (1970) Hissin and Hiff (1976) and Draper and Hadley (1990), respectively.

\section{7-Histopathological examination of the heart}

The heart sample was fixed in $10 \%$ neutral buffered formaldehyde solution at $\mathrm{pH} 7.5$ and cleared in xylol and embedded in paraffin. 4-5 $\mu \mathrm{m}$ thick section were prepared and stained with Hematoxylin and Eosin (H\&E) for subsequent histopathological examination according to Bancroft et al, (1996).

\section{C-Statistical analysis}

All the obtained data were statistically analyzed by SPSS computer soft ware. The calculated occurred by analysis of variance ANOVA and follow up test LSD by SPSS ver.11 according to Armitage and Berry (1987).

\section{RESULTS AND DISSCUSION}

\section{Nutritional Results}

Feeding and growth performance in terms of food intake, body weight gain, food efficiency ratio and protein efficiency ratio of control ($\mathrm{ve})$, control (+ve) and myocardial damage rat groups treated with moringa 
oleifera leaves, seed powder and water extract were presented in table (1). In comparing with control (-ve) group, the myocardial damage control (+ve) group showed significant decrease in weight gain; food intake ,feed efficiency ratio(FER),protein efficiency ratio(PER), The myocardial damage rat groups treated with Moringa oleifera leaves, seed powder and water extract showed significant increase in weight gain; food intake ,feed efficiency ratio(FER) and protein efficiency ratio(PER) when compared with control (+ve) group. On the other hand, there were non-significant difference in weight gain; food intake, feed efficiency ratio(FER) and protein efficiency ratio(PER) in all treated rat groups when compared with control (-ve) group. The improvement of weight gain, FER and PER in rats administration of moringa oleifera may be attributed to the biologically active components as moringa oleifera,. The leaves are highly essential nutritious when compared to other parts, being a source of protein, $\beta$ carotene, vitamins $\mathrm{A}, \mathrm{B}, \mathrm{C}$ and $\mathrm{E}$, riboflavin, nicotinic acid, folic acid, pyridoxine, amino acids, minerals and various phenolic compounds (Khalafalla et.al.,2010).The chemical constituents in the dried, powdered leaves of moringa oleifera. contained $28.7 \%$ crude protein, $7.1 \%$ fat, $10.9 \%$ ash, $44.4 \%$ carbohydrates, $3.0 \mathrm{mg}$ calcium and $103.1 \mathrm{mg}$ of iron per $100 \mathrm{~g}, 161 \mu \mathrm{g} \beta$-carotene/g, The dried moringa oleifera leaves extract contained $22.6 \%$ fiber, $2.73 \%$ ash, $3.78 \%$ protein, $9.53 \%$ total sugars, $0.00746 \%$ calcium, $0.0549 \%$ iron, and $0.0468 \%$ total catechins/flavonoids $(0.0323 \%$ epicatechin). No carotenoids, vitamin C, or phytosterols were present in the extract (Teixeira et.al.,2014). The moringa oleifera was high concentrations of ascorbic acid; oestrogenic substances and $\beta$-sitosterol; iron; calcium; phosphorus; copper; vitamins A, B and C; $\alpha$-tocopherol; riboflavin; nicotinic acid; folic acid; pyridoxine; $\beta$-carotene; protein; and in particular essential amino acids such as methionine, cysteine, tryptophan, and lysine present in Moringan leaves and make it ideal dietary supplement. (Westerterp 2004) 
- Nutraceutical effects of Moringa oleifera, leaves, seed and extract on side effects of Isoproterenol

Table (1): Nutritional indicators of normal control and myocardial infarction rat groups treated with Moringa oleifera leaves powder, seed powder and water extract at the end of the experimental period

\begin{tabular}{|c|c|c|c|c|c|c|}
\hline \multicolumn{3}{|l|}{ Groups } & $\begin{array}{c}\text { Weight gain } \\
(\mathrm{g})\end{array}$ & $\begin{array}{c}\text { Food intake } \\
(\mathrm{g} / \mathrm{d})\end{array}$ & FER & PER \\
\hline \multicolumn{3}{|c|}{ Control-ve } & $72.51 \pm 3.11^{\mathrm{a}}$ & $19.77 \pm 1.94^{\mathrm{a}}$ & $0.061 \pm 0.001^{\mathrm{b}}$ & $0.305 \pm 0.016^{\mathrm{a}}$ \\
\hline \multirow{4}{*}{$\begin{array}{l}\text { myocardial } \\
\text { infarcted } \\
\text { rats groups }\end{array}$} & \multicolumn{2}{|c|}{ Control +ve } & $33.14 \pm 2.91^{\mathrm{c}}$ & $15.21 \pm 1.14^{\mathrm{b}}$ & $0.036 \pm 0.003^{\mathrm{a}}$ & $0.181 \pm 0.013^{\mathrm{c}}$ \\
\hline & \multirow{3}{*}{$\begin{array}{c}\text { Treated } \\
\text { with } \\
\text { Moringa }\end{array}$} & Leaves & $59.40 \pm 4.78^{b}$ & $19.31 \pm 1.75^{\mathrm{a}}$ & $0.051 \pm 0.004^{\mathrm{a}}$ & $0.256 \pm 0.011^{\mathrm{ab}}$ \\
\hline & & seed & $60.77 \pm 6.22^{\mathrm{ab}}$ & $19.08 \pm 1.86^{\mathrm{a}}$ & $0.053 \pm 0.003^{\mathrm{a}}$ & $0.265 \pm 0.002^{\mathrm{ab}}$ \\
\hline & & extract & $66.11 \pm 6.88^{a}$ & $19.80 \pm 1.66^{\mathrm{a}}$ & $0.055 \pm 0.001^{\mathrm{a}}$ & $0.278 \pm 0.012^{\mathrm{ab}}$ \\
\hline
\end{tabular}

Each value is the mean $\pm \mathrm{SD}$

Mean values in each column having different superscript (a, b, c \& d) are significantly different at $\mathrm{P}<0.05$ feed efficiency ratio(FER), protein efficiency ratio(PER)

\section{Biochemical Results}

Table (2) presented some serum lipid parameters. In comparing with control negative rat groups, the levels of CHO, TG, LDL-c,VLDL-c, and atherogenic indices (CHO/HDLc).in control positive rat groups were significantly increased but HDLc was significant decreased. On the other hand, there were non-significant difference in serum levels of $\mathrm{CHO}, \mathrm{TG}$, HDLc , LDL-c, VLDL-c and atherogenic indices (CHO/HDLc) among Moringa oleifera leaves, seed powder and water extract rat groups In comparing with control negative rat groups The observed effects of Moringa oleifera leaves, seed powder and water extract on lipid profile and $\mathrm{CHO} / \mathrm{HDLc}$ could be related to antioxidant activity which might attribute to those identified compounds such as, flavones, alkaloids, and so on Nandave et al.,(2009). It is believed that the treatment with crude extract of Moringa. oleifera led to an increased serum HDL level and decreased levels of total cholesterol, LDL, and triglyceride. Thus, it can be concluded that leaves of Moringa oleifera possess cardioprotective potential Similar results were obtained by Mbikay,(2012) Illustrated that the atherogenic index is regarded as a marker for various cardiovascular disorders; the higher the value, the higher the risk of developing cardiovascular disease and vice versa High-fat 
diet exposure resulted in the increased atherogenic index. Treatment with $200 \mathrm{mg} / \mathrm{kg}$ and $400 \mathrm{mg} / \mathrm{kg}$ of Moringa oleifera showed a significantly decrease the atherogenic index and thus provides cardio protection. The decreased atherogenic index by Moringa oleifera thus supports the cardioprotectant Nambiar et al. (2010) examined the anti-dyslipidemic effects of Moringa. oleifera in 35 type 2 diabetic subjects. The treated group received $4.6 \mathrm{~g}$ of a leaf powder in a tablet form daily for 50 days. Compared with the control group, the treated subjects experienced a $1.6 \%$ decrease in total plasma cholesterol and a 6.3\% increase in HDL.Comparing this study with the previous studies suggests that higher doses may be more effective.

Table (2): Effect of experimental Moringa oleifera leaves, seed powder and water extract on some serum lipid pattern and atherogenic index (CHO /HDL) of control and myocardial infarction rat groups at the end of study

\begin{tabular}{|c|c|c|c|c|c|c|c|c|}
\hline $\mathrm{CHO} / \mathrm{HDL}$ & VLDL & LDL & HDL & TG & $\mathrm{CHO}$ & \multicolumn{3}{|c|}{${ }_{\text {Groups }}^{\text {Variables }}$} \\
\hline $3.01 \pm b$ & $14.06 \pm b$ & $60.01 \pm b c$ & $36.71 \pm \mathrm{a}$ & $70.33 \pm b$ & $110.77 \pm b c$ & \multirow{2}{*}{\multicolumn{3}{|c|}{ Control -ve }} \\
\hline 0.44 & 1.71 & 6.22 & 3.14 & 9.01 & 11.84 & & & \\
\hline $12.28 \pm \mathrm{a}$ & $30.28 \pm \mathrm{a}$ & $204.17 \pm \mathrm{a}$ & $20.77 \pm b$ & $151.41 \pm \mathrm{a}$ & $255.22 \pm \mathrm{a}$ & \multirow{2}{*}{\multicolumn{2}{|c|}{ Control+ve }} & heart \\
\hline 1.77 & 3.18 & 21.11 & 2.61 & 14.96 & 25.61 & & & damage \\
\hline $3.47 \pm b$ & $14.22 \pm b$ & $72.81 \pm b$ & $35.11 \pm \mathrm{a}$ & $71.14 \pm b$ & $122.14 \pm b$ & Leaves & \multirow{6}{*}{$\begin{array}{l}\text { Treated } \\
\text { with } \\
\text { Moringa }\end{array}$} & groups \\
\hline 0.53 & 1.60 & 8.14 & 4.02 & 8.11 & 14.96 & & & \\
\hline $3.89 \pm b$ & $14.82 \pm b$ & $82.34 \pm b$ & $33.60 \pm \mathrm{a}$ & $74.12 \pm b$ & $130.76 \pm b$ & seed & & \\
\hline 0.47 & 1.55 & 9.11 & 3.71 & 7.90 & 16.33 & & & \\
\hline $3.71 \pm b$ & $15.04 \pm \mathrm{b}$ & $78.17 \pm b$ & $34.30 \pm \mathrm{a}$ & $75.22 \pm b$ & $127.51 \pm b$ & extract & & \\
\hline 0.51 & 1.33 & 8.60 & 3.22 & 8.61 & 15.60 & & & \\
\hline
\end{tabular}

Each value is the mean $\pm \mathrm{SD}$

Mean values in each column having different superscript ( $a, b, c \& d)$ are significantly different at $\mathrm{P}<0.05$ cholesterol, $(\mathrm{CHO})$, triglyceride (TG), high density lipoprotein (HDLc),low density lipoprotein (LDLc),very low density lipoprotein (VLDLc),

Table (3) showed the effect of Moringa oleifera leaves, seed powder and water extract on cardiac markers in serum The levels of amino transferase, (AST,ALT), alkaline phosphates (ALP) and Lactatet 
dehydrogenase(LDH) were significantly increased in control positive rat groups, In comparing with Moringa oleifera treated rat groups and control negative rat groups. But the levels of cardiac markers in serum were significantly increased in Moringa oleifera treated rat groups when compared to control negative rat groups On the other hand, there were nonsignificant difference in serum levels of cardiac markers among treated rat groups with moringa oleifera leaves, seed powder and water extract These results agree with .Das et al., (2012) have shown that in mice fed with a high-fat diet, an aqueous extract of Moringa oleifera leaves and seeds protects against liver damage as demonstrated by reductions in tissue histopathology and serum activities of marker enzymes aspartate aminotransferase (AST), alanine aminotransferase (ALT), and alkaline phosphatase (ALP) as well as reduced lipid peroxidation and increases in reduced glutathione Nandave et al.,(2009). Demonstrated that the cardioprotective effect of $\mathrm{N}, \alpha$-L-rhamnopyranosyl vincosamide, an indole alkaloid isolated from the leaves of Moringa oleifera Anwar,et al.,( 2007) Observed that the medicinal properties of the plant's edible parts have been recognized by both the Ayurvedic and Unani systems of medicine in India The various plant parts have wide medicinal applicability for the treatment of cardiovascular diseases as the roots, leaves, gum, flowers, and seed infusion contain nitrile, mustard oil glycosides, and thiocarbamate glycosides as their important bioactive constituents, which are thought to be responsible for their diuretic, cholesterol lowering, and antiulcer properties Sidney et al ,2015) studies have shown the aqueous, hydroalcohol, or alcohol extracts of Moringa. oleifera leaves possess a wide range of additional biological activities including antioxidant, tissue protective the liver, kidneys, heart, testes, and lungs, analgesic, antiulcer, antihypertensive, radioprotective, and immunomodulatory actions. because its cntains awide variety of polyphenols and phenolic acids as well as flavonoids, glucosinolates, and possibly alkaloids is believed to be responsible for the observed effects. 
Table (3): Effect of experimental Moringa oleifera leaves, seed powder and water extract on some cardiac markers AST, ALT, ALP and LDH of control and myocardial infarction rat groups at the end of study

\begin{tabular}{|c|c|c|c|c|c|c|}
\hline $\begin{array}{l}\mathrm{LDH} \\
(\mathrm{I} \mu / 1) \\
\end{array}$ & $\begin{array}{c}\text { ALP } \\
(\mu / \mathrm{ml})\end{array}$ & $\begin{array}{c}\text { AST } \\
(\mu / \mathrm{ml})\end{array}$ & $\begin{array}{c}\text { ALT } \\
(\mu / \mathrm{ml}))\end{array}$ & Groups & & Variables \\
\hline $125.31 \pm \mathrm{c}$ & $70.14 \pm c$ & $53.21 \pm c$ & $40.11 \pm c$ & \multirow{2}{*}{\multicolumn{3}{|c|}{ Control -ve }} \\
\hline 11.78 & 6.99 & 5.60 & 4. 40 & & & \\
\hline $317.33 \pm \mathrm{a}$ & $370.11 \pm \mathrm{a}$ & $335.40 \pm \mathrm{a}$ & $293.41 \pm \mathrm{a}$ & \multirow{2}{*}{\multicolumn{2}{|c|}{ Control+ve }} & heart \\
\hline 39.67 & 41.44 & 35.66 & 21.59 & & & damage \\
\hline $170.21 \pm b$ & $185.11 \pm b$ & $170.33 \pm b$ & $140.11 \pm b$ & Leaves & \multirow{6}{*}{$\begin{array}{c}\text { Treated } \\
\text { with } \\
\text { Moringa }\end{array}$} & groups \\
\hline 18.33 & 20.15 & 16.11 & 12.45 & & & \\
\hline $168.44 \pm b$ & $187.21 \pm b$ & $167.33 \pm b$ & $145.22 \pm b$ & seed & & \\
\hline 16.45 & 19.13 & 18.74 & 13.70 & & & \\
\hline $160.22 \pm b$ & $180.77 \pm b$ & $160.41 \pm b$ & $146.77 \pm b$ & extract & & \\
\hline 17.01 & 19.22 & 17.75 & 13.09 & & & \\
\hline
\end{tabular}

Each value is the mean $\pm \mathrm{SD}$

Mean values in each column having different superscript ( $a, b, c \& d)$ are significantly aminotransferase (AST), alanine aminotransferase (ALT), and alkaline phosphatase (ALP) Lactatet dehydrogenase(LDH)

Data in table (4) illustrated the cardiac markers in heart tissue functions in the five rat groups. Control positive rat groups showed significant increase in heart tissue Lactatet dehydrogenase(LDH), Nitric oxide(NO)and Xanthine oxidase (XO) compared to control negative rat groups Administration of Moringa oleifera leaves, seed powder and water extract to rat groups showed non significant changes compared with control negative rat groups exception Xanthine oxidase in heart tissue but showed significant decrease compared with +ve control rat groups. It is known that the increase of cardiac markers in heart tissue indicated abnormal heart functions and restoration of normal levels of these enzymes These results agree with Panda et al.,( 2012). Illustrated that the various derivatives of salicylic acid, gallic acid, coumarin acid, and caffeic acid also exist in extracts of M. oleifera. In addition, indole alkaloid N, $\alpha$-L-rhamnopyranosyl 
vincosamide has been isolated from $\mathrm{M}$. oleifera leaves and shown to exert a cardioprotective effect on rats Nandave et al.,(2009) Reported that the treatment of Moringa. oleifera resulted in significant favorable modulation of the biochemical enzymes superoxide dismutase, catalase, glutathione peroxidase, lactate dehydrogenase, and creatine kinase-MB compared to the ISP control group. Moringa treatment significantly prevented the rise in lipid peroxidation in myocardial tissue. Furthermore, M. oleifera also prevented the deleterious histopathological and ultrastructural perturbations caused by ISP. Based on the results of the present study, it can be concluded that M. oleifera extract possesses significant cardioprotective effect, which may be attributed to its antioxidant, antiperoxidative, and myocardial preservative properties. Randriamboavonjy et al., (2016 ) Moringa oleifera seed powder treatment did not modify blood pressure in spontaneous hypertensive rats but reduced nocturnal heart rate and improved cardiac diastolic function (reduction of isovolumetric relaxation time and deceleration time of the $\mathrm{E}$ wave, increase of ejection volume and cardiac output compared to nontreated spontaneous hypertensive rats Left ventricular anterior wall thickness, interseptal thickness on diastole, and relative wall thickness were reduced after Moringa oleifera seed powder treatment. Furthermore, we found a significant reduction of fibrosis in the left ventricle of Moringa oleifera seed powder treated spontaneous hypertensive rats this antihypertrophic and antifibrotic effect of Moringa oleifera seed powder was associated with increased expression of peroxisome proliferator-activated receptor and, reduced cardiac triglyceride level, and enhanced plasmatic prostacyclins. 
Table (4): Effect of experimental Moringa oleifera leaves, seed powder and water extract on some cardiac markers in heart tissue LDH, NO and XO of control and myocardial infarction rat groups at the end of study

\begin{tabular}{|c|c|c|c|c|c|}
\hline $\begin{array}{c}\mathrm{XO} \\
(\mathrm{nmol} / \mathrm{min} / \mathrm{mg} \\
\text { protine })\end{array}$ & $\begin{array}{c}\mathrm{N} 0 \\
(\mu \mathrm{mol} / \mathrm{min} / \mathrm{mg} \\
\text { protine })\end{array}$ & $\begin{array}{c}\mathrm{LDH} \\
(\mu \mathrm{mol} / \mathrm{min} / \mathrm{mg} \\
\text { protine })\end{array}$ & Groups & & Variables \\
\hline $2.22 \pm \mathrm{c}$ & $13.11 \pm b c$ & $8.66 \pm b c$ & \multirow{2}{*}{\multicolumn{3}{|c|}{ Control -ve }} \\
\hline 0.55 & 2.41 & 1. 10 & & & \\
\hline $16.33 \pm \mathrm{a}$ & $65.11 \pm \mathrm{a}$ & $35.75 \pm \mathrm{a}$ & \multirow{2}{*}{\multicolumn{2}{|c|}{ Control+ve }} & \multirow{8}{*}{$\begin{array}{c}\text { heart } \\
\text { damage } \\
\text { groups }\end{array}$} \\
\hline 4.19 & 6.77 & 4.11 & & & \\
\hline $4.33 \pm b$ & $15.07 \pm b$ & $10.11 \pm b$ & Leaves & \multirow{6}{*}{$\begin{array}{l}\text { Treated } \\
\text { with } \\
\text { Moringa }\end{array}$} & \\
\hline 0.88 & 2.51 & 1.65 & & & \\
\hline $5.22 \pm b$ & $16.88 \pm b$ & $10.14 \pm b$ & seed & & \\
\hline 1.01 & 3.10 & 1.44 & & & \\
\hline $4.11 \pm b$ & $15.33 \pm b$ & $9.75 \pm b$ & extract & & \\
\hline 0.94 & 2.11 & 1.29 & & & \\
\hline
\end{tabular}

Each value is the mean $\pm \mathrm{SD}$

Mean values in each column having different superscript (a, b, c \& d) are significantly Lactatet dehydrogenase(LDH),Nitric oxide(NO)and Xanthine oxidase (XO)

Data in table (5) illustrated the antioxidant system enzyme in the five rat groups. In comparing with -ve control rat groups, the myocardial damage +ve control rat groups showed significant decrease in serum values of superoxide dismutase( SOD), catalase (CAT) and glutathione-S-transferase (GST) but significant increase in serum Malondialdehyde (MDA. The moringa oleifera leaves, seed powder and water extract showed a significant increase compared to +ve control rat groups but showed non significant different in (SOD), (CAT), (GST) and (MDA) compared to - ve control rat groups On the other hand, there were a significant increase in serum Malondialdehyde (MDA) in + ve control rat groups compared to all treated rats and - ve control rat groups these results agree with. Verma et al.,(2009) and Sreelatha and Padma,. (2011). showed that the Phenolic compounds are commonly found in both edible and other traditional medicinal plants, of 
Moringa oleifera and they have been reported to have multiple biological activities, including free radical scavenging activity. Antioxidants in food appear to play an essential role in the prevention of oxidative stress-related diseases/disorders and in the reduction of total mortality Typical phenolics that Possess antioxidant activity is mainly phenolic acids and flavanoids. Flavonoids commonly accumulate in the epidermal cells of plant organs such as flowers, leaves, stems, roots, seeds and fruits, being found in glycosidic form (glycosides) and non-glucosidic form Showed the strong in vitro antioxidant properties of the methanolic extract of Moringa oleifera edible parts. This antioxidant activity of Moringa oleifera extracts is due to the presence of various bioactive compounds such as chlorogenic acid, rutin, quercetin Glucoside, and kaempferol rhamnoglucoside furthermore, the extract of Moringa oleifera leaves and other parts have been shown to have potent antioxidant action in vivo Wojdylo et al (2007) Illistreted that the Moringa oleifera contains certain phenolic compounds also may induce production of glutathione-S-transferase and other antioxidant enzymes. The ability of certain phenolic compound to bind to minerals may be beneficial in some cases, since copper and iron can be initiators of hydroxyl radical production by the Fenton and Haber-Weiss reactions Jaiswal et al. (2013) have investigated the antioxidant activity of an aqueous extract of Moringa oleifera leaves in normal and diabetic rats. Oxidative free radical scavenging enzymes were measured in response to $200 \mathrm{mg} / \mathrm{kg}$ of lyophilized powder. A significant increase in activities of superoxide dismutase, catalase, and glutathione S-transferase and a decrease in lipid per oxidation were observed. It was suggested that the high phenolic and flavonoid contents in the extract can protect against oxidative damage in normal diabetic and heart patients Vongsak et al. (2014) have conducted a quantitative analysis of an ethanol extract of Moringa oleifera leaves by HPLC, and have shown that the average values for crypto-cholorgenic acid, isoquercetin, and astragalin in the dried extract were $0.081 \%, 0.120 \%$, and $0.153 \%$, respectively. They have suggested that these compounds and this analysis may serve as a guideline for the standardization of Moringa oleifera 
extracts. However, these standards could only be applied to ethanol extracts and not to aqueous extracts

Table (5): Effect of experimental Moringa oleifera leaves, seed powder and water extract on SOD, GST, CAT and MDA in serum of control and myocardial infarction rat groups at the end of study

\begin{tabular}{|c|c|c|c|c|c|c|}
\hline $\begin{array}{c}\text { Malondialdehyde } \\
\operatorname{MDA}(\mu / \text { dl } 1)\end{array}$ & $\begin{array}{c}\text { glutathione-S- } \\
\text { transferase (GST) } \\
(\mu / \mathrm{dl} l)\end{array}$ & $\begin{array}{l}\text { catalase } \\
(\mathrm{CAT}) \\
(\mu / \mathrm{dl} 1)\end{array}$ & $\begin{array}{l}\text { Superoxide } \\
\text { dismutas } \\
\text { SOD }(\mu / \text { dl } 1)\end{array}$ & \multicolumn{3}{|c|}{ Groups } \\
\hline $8.11 \pm b$ & $115.77 \pm \mathrm{a}$ & $120.01 \pm \mathrm{a}$ & $39.22 \pm \mathrm{a}$ & \multirow{2}{*}{\multicolumn{3}{|c|}{ Control-ve }} \\
\hline 1.87 & 12.69 & 9.10 & 5.08 & & & \\
\hline $25.11 \pm \mathrm{a}$ & $60.31 \pm b$ & $35.60 \pm b$ & $13.14 \pm \mathrm{c}$ & \multirow{2}{*}{\multicolumn{2}{|c|}{ Control+ve }} & \multirow{8}{*}{$\begin{array}{l}\text { heart } \\
\text { damage } \\
\text { groups }\end{array}$} \\
\hline 3.47 & 7.88 & 5.68 & 2. 15 & & & \\
\hline $9.77 \pm b$ & $114.33 \pm \mathrm{a}$ & $117.93 \pm \mathrm{a}$ & $36.71 \pm \mathrm{a}$ & Leaves & \multirow{6}{*}{$\begin{array}{c}\text { Treated } \\
\text { with } \\
\text { Moringa }\end{array}$} & \\
\hline 1.38 & 12.44 & 10.19 & 4.05 & & & \\
\hline $9.04 \pm b$ & $109.22 \pm \mathrm{a}$ & $119.88 \pm \mathrm{a}$ & $34.99 \pm \mathrm{a}$ & seed & & \\
\hline 1.54 & 10.66 & 8.47 & 3.45 & & & \\
\hline $9.77 \pm b$ & $110.25 \pm \mathrm{a}$ & $126.19 \pm \mathrm{a}$ & $35.71 \pm \mathrm{a}$ & extract & & \\
\hline 1.61 & 11.08 & 7.57 & 3.32 & & & \\
\hline
\end{tabular}

Each value is the mean $\pm \mathrm{SD}$

Mean values in each column having different superscript (a, b, c \& d) are significantly

\section{Histopathological Examination of Heart-:}

Microscopically heart of-ve control rat groups revealed the normal myocardial muscle fibers (pict.1) Conversely, heart of rat from Isoproterenol non treated +ve control rat groups showed focal necrosis of myocardial muscle fibers associated with leucocytic cells infiltration, inflammatory cells and intermuscular edema (pict.2). However, heart of rats from treated with Moringa oleifera leaves, seed powder and water extract revealed no histopathological changes (pict 3,4,5). The histopathological results denoted some changes but less than that of the +ve control rat groups These histopathological results changes agree with Panda et al.,( 2012)This alkaloid in Moringa oleifera leaves, seed powder and water extract when 
administered at an oral dose of $40 \mathrm{mg} / \mathrm{kg}$ per day for 7 days markedly reduced isoproterenol-induced cardiotoxicity in rats. The cardioprotective effects were demonstrated by decreases in serum cardiac biomarkers, increases in cellular antioxidants and antioxidant enzymes, a reduction in cardiac necrosis, a decrease in cardiac lipid peroxidation, and a reduction in cardiac histopathology and electrocardiographic (ECG) changes Nandave et al.,(2009).Showed that the rats were treated daily with saline, isoproterenol, or isoproterenol plus the leaf extract $(200 \mathrm{mg} / \mathrm{kg}$ ) orally for 1 month. The M. oleifera leaf extract prevented biochemical, histopathological, and ultrasound changes in the heart induced by isoproterenol. The extract prevented isoproterenol-induced hemodynamic changes in the heart including changes in heart rate, left ventricular end-diastolic pressure, left ventricular peak positive pressure, and left ventricular negative pressure .The myocardial infarction by isoproterenol (ISP) group showed the greatest aortic changes compared with the control groups.From obtained results It can be recommend that the increase consumption of Moringa oleifera leaves, seed powder and water extract of their effective impact in reducing the side effects of isoproterenol rats, which proved some chemical analyses of serum, and confirmed by the analysis of histopathological tissue of the heart, and nutritional status, and recommended research also need to enter the Moringa oleifera leaves, seed powder and water extract the food plan of myocardial infarction diet and general beverages in quantities which achieved results on rats, which have been turned into quantities to humans, dose.

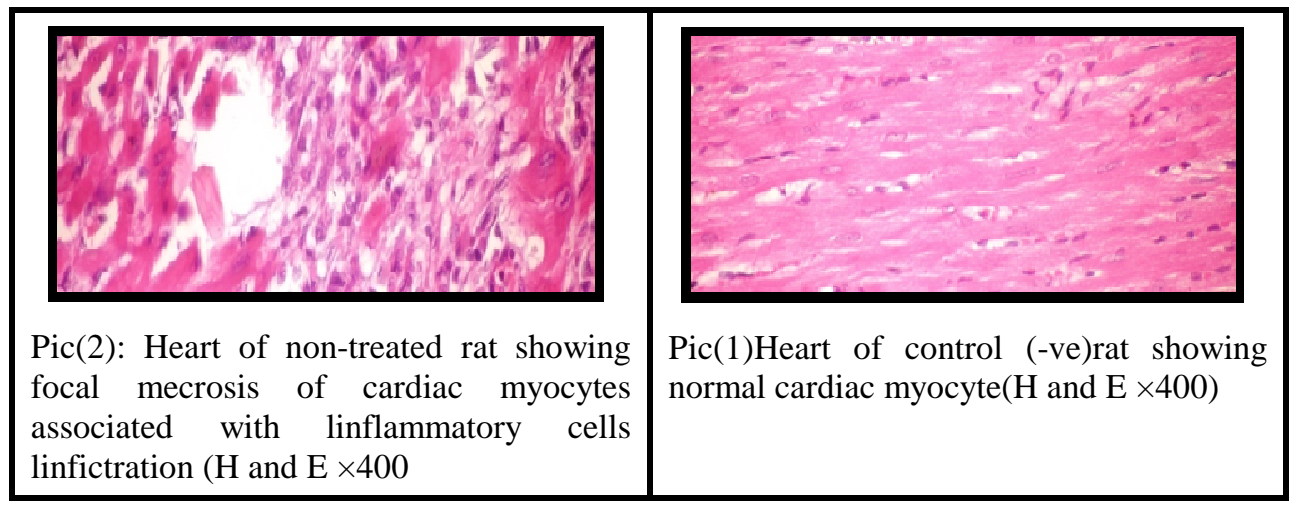




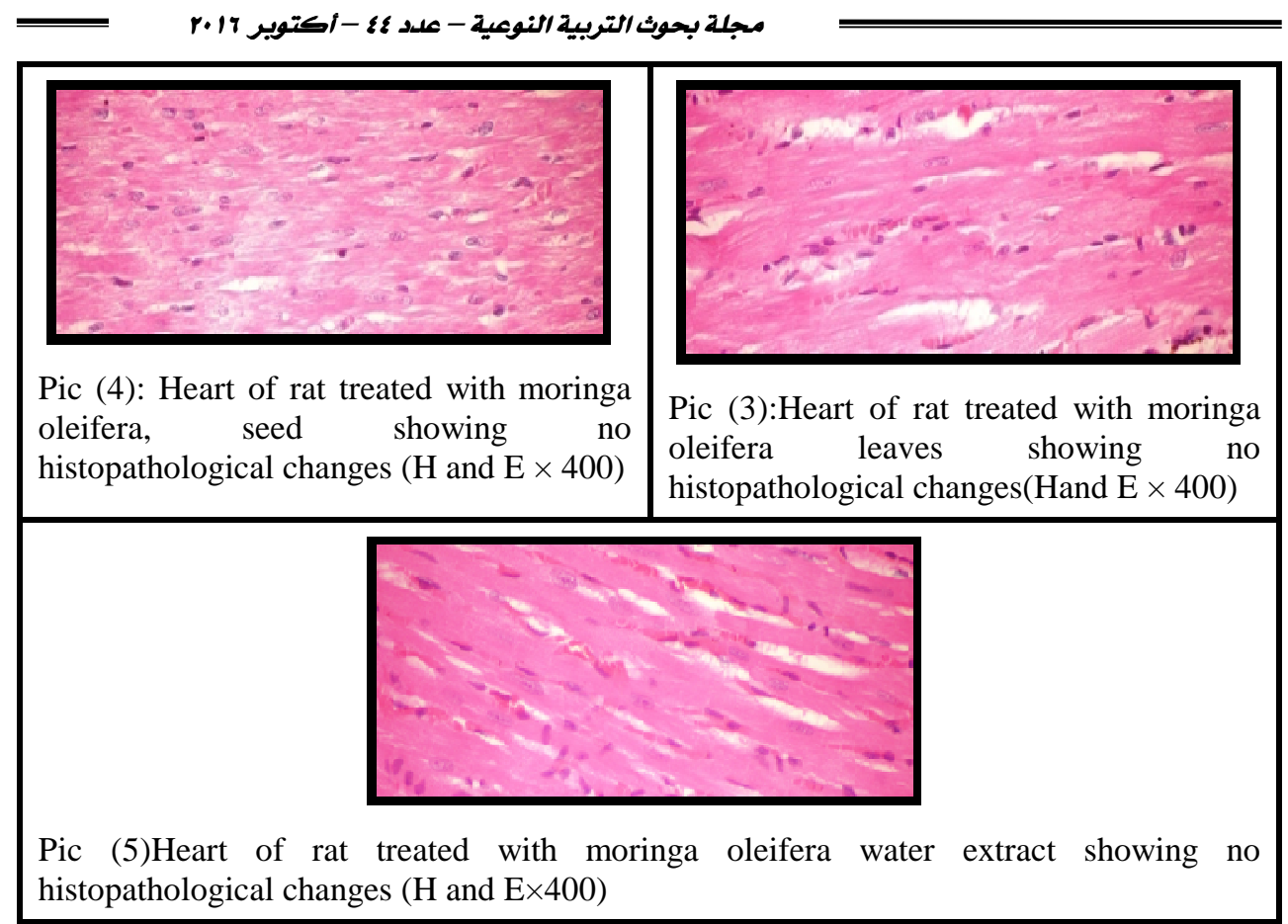

\section{REFERENCES}

Adedapo AA, Mogbojuri OM, Emikpe BO.( 2009). Safety evaluations of the aqueous extract of the leaves of Moringa oleifera in rats. J Med Plant 3: 586-591.

Goyal S, Siddiqui MK, Siddiqui KM, Arora S, Mittal R, Joshi S, Arya DS (2009) Cardioprotective effect of 'Khamira Abresham Hakim Arshad Wala' a unani formulation in isoproterenol-induced myocardial necrosis in rats. Exp Toxicol Pathol 62:61-74

Adams MR (2002) Prevention of myocardial infarction. Int Med J 32:595-600

Bergmever,H.U.(1974)"methods of enzymatic analysis bergmever(ed)", Verlag Chemie Weinheim Academic press New York

Caband,P.and Wroblewski,F.(1958) Colorimetric measurement of lactic dehydrogen activity of body fluids Am.J.Clin.Pathol.30:234

Williams, S. (1984): "Nitrated and nitrites in meat, in official methods of analysis of the association of official analytical chemists" ,AOAC, Arlington, Virginia, USA. 
- Nutraceutical effects of Moringa oleifera, leaves, seed and extract on side effects of Isoproterenol

Whellan DJ (2005) Heart failure disease management: implementation and outcomes. Card Rev 13:231-239

Sasikumar CS, Shyamala Devi CS (2000) Protective effect of Abana, a polyherbal formulation, on isoproterenol-induced myocardial infarction in rats. Indian J Pharmacol 32:198-201

Ebenezar KK, Sathish V, Devaki T (2003) Effect of arginine and lysine on mitochondrial function during isoproterenol induced myocardial infarction. Nutr Res 23:1269-1277

Kumar S. P,. Mishra, D. Ghosh G, and. Panda, C. S (2010. )“Medicinal uses and pharmacological properties of Moringa oleifera," International Journal of Phytomedicine, vol. 2, no. 3, pp. 210-216,

Ghasi, S. E. Nwobodo, and. Ofili, J. O(2000) "Hypocholesterolemic effects of crude extract of leaf of Moringa oleifera Lam in high-fat diet fed wistar rats," Journal of Ethnopharmacology, vol. 69, no. 1, pp. 21-25,

Chagoya de Sanchez V, Hernandez-Munoz R, Lopez-Barrera F, (1997) Sequential changes of energy metabolism and mitochondrial function in myocardial infarction induced by isoproterenol in rats: a long-term and integrative study. Can J Physiol Pharmacol.;75:1300-1311

Khalafalla, M.M.;Abdellatef, E.;Dafalla, H.M.; Nassrallah, A.A.;Aboul-Enein K.M.;Lightfoot, D.A.; El-Deeb, F.E.; El-Shemy, H.A. . ( 2010) Active principle from Moringa oleifera Lam leaves effective against two leukemias and a hepatocarcinoma. Afr. J. Biotechnol, 9, 8467-8471.

Westerterp, K. R (2004)“Diet induced thermogenesis," Nutrition and Metabolism, vol. 1 , article 5,

Yates JC, Dhalla NS(1975) Induction of necrosis and failure in the isolated perfused rat heart with oxidized isoproterenol. J Mol Cell Cardiol.;7:807816.

Padmanabhan M, (2007) Prince PSM. S-allylcysteine ameliorates isoproterenolinduced cardiac toxicity in rats by stabilizing cardiac mitochondrial and lysosomal enzymes. Life Sci.;80:972-978Aje T. O., Miller M. (2009). Cardiovascular disease: a global problem extending into the developing world. World J. Cardiol. 1, 3-1010.4330/wjc.v1.i1.3 


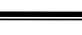
مجلة بحوث التربية النوعية - عدد \&\{ - أكتوير 17.

Hossain P., Kawar B., El Nahas M. (2007). Obesity and diabetes in the developing world - a growing challenge. N. Engl. J. Med. 356, 21321510.1056/NEJMp068177

Yusuf S., Reddy S., Ounpuu S., Anand S. (2001). Global burden of cardiovascular diseases: Part II: variations in cardiovascular disease by specific ethnic groups and geographic regions and prevention strategies. Circulation 104, 2855-286410.1161/hc4701.099488

Wild S., Roglic G., Green A., Sicree R., King H. (2004). Global prevalence of diabetes: estimates for the year 2000 and projections for 2030. Diabetes Care27, 1047-105310.2337/diacare.27.5.1047References

Teixeira EMB, Carvalho MRB, Neves VA, Silva MA, Arantes-Pereira L.( 2014). Chemical characteristics and fractionation of proteins from Moringa oleifera Lam. leaves. Food Chem 147: 51-54

Mbikay M,(2012)“Therapeutic potential of Moringa oleifera leaves in chronic hyperglycemia and dyslipidemia: a review," Frontiers in Pharmacology, vol. 3, no. 24, pp. 1-12

Nandave M,. Ojha S. K, Joshi S.,. Kumari S, and. Arya D. S, (2009) "Moringa oleifera leaf extract prevents isoproterenol-induced myocardial damage in rats: Evidence for an antioxidant, antiperoxidative, and cardioprotective intervention," Journal of Medicinal Food, vol. 12, no. 1, pp. 47-55

Randriamboavonjy JI, Loirand G, Vaillant N, Lauzier B, Derbré S, Michalet S, Pacaud P, Tesse A.(2016) Cardiac Protective Effects of Moringa oleifera Seeds in Spontaneous Hypertensive Rats American Journal of Hypertension, Ltd

Wojdylo, A.; Oszmianski, J.; Czemerys, R(2007). Antioxidant activity and phenolic compounds in 32 selected herbs. Food Chem., 105, 940-949.

Jaiswal D, Rai PK, Mehta S, et al.( 2013). Role of Moringa oleifera in regulation of diabetes-induced oxidative stress. Asian Pac J Trop Biomed 6: 426432.

Vongsak B, Sithisam P, Gritsanapan W. (2014). Simultaneous HPLC quantitative analysis of active compounds in leaves of Moringa oleifera Lam. J Chromatogr Sci 52: 641-645 
$=$ Nutraceutical effects of Moringa oleifera, leaves, seed and extract on side effects of Isoproterenol

Verma, A.R.; Vijayakumar, M.; Mathela, C.S.; Rao, C.V(2009). In vitro and in vivo antioxidant properties of different fractions of Moringa oleifera leaves. Food Chem. Toxicol., 47, 2196-2201.

Sreelatha, S.; Padma, P.R.( 2011) Modulatory effects of Moringa oleifera extracts against hydrogen peroxide-induced cytotoxicity and oxidative damage. Hum. Exp. Toxicol., 30, 1359-1368

Anwar, F.; Latif, S.; Ashraf, M.; Gilani, A.H.( 2007) Moringa oleifera: A food plant with multiple medicinal uses. Phytother. Res., 21, 17-25.

Das N, Sikder K, Ghosh S, et al.( 2012.) Moringa oleifera Lam leaf extract prevents early liver injury and restores antioxidant status in mice fed with high-fat diet. Indian J Exp Biol 50: 404-412

Panda S, Kar A, Sharma P, Sharma A. (2012.) Cardioprotective potential of $\mathrm{N}, \alpha$-1-rhamnosylpyranosyl vincosamide, an indole alkaloid, isolated fromthe leaves ofMoringa oleifera in isoproterenol induced cardiotoxic rats: in vivo and in vitro studies. Bioorg Med Chem Lett. DOI:10.1016/j.bmcl..12.060.

Nambiar VS, Guin P, Parnami S, Daniel M.( 2010.) Impact of antioxidants from drumstick leaves on the lipid profile of hyperlipidemics. J Herb Med Toxicol 4: 165-172

Sidney J. Stohs* and Michael J. Hartman (2015) Review of the Safety and Efficacy of Moringa Oleifera Phytother. Res. 29: 796-804

Artimage, G.Y. and W.G. Berry,(1987):Statistical Methods 7th Ed. Ames, Iowa State University Press, 39-63.

Friedwald , W.T,: Levy ,R.I. and Fredrik-Son \& D.S.(1972):Estimation of concentration of low-density lipoprotein separated by there different method.Clin. Chem .,28:2077.

Bergmeyer, H. U. and Horder, M. (1980): Methods for the measurement of catalyuc concentration of enzymes. J. Clin. Chem. Clin. Biochem., 18:521-534.

Misra, H.P. and Fridovich, I. (1972): The role of superoxide anion in the antioxidant epinephrine and a single assay of superoxide dismutase. J Biol Chem.247:3170-5. 


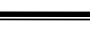
مجلة بحوث التربية النوعية - عدد \&8 - أكتوير 19 19

Kind, P.R and King, E.J. (1954): Estimation of alkaline phosphatase activity by determination of hydrolyzed phenol with aminoantipyrene. J. Clin.Path, $7: 322$.

Cohen, G., Dembuic D. and Marcus J. (1970). Measurement of catalase activity in tissue extract. Anal. Biochem., 34, 30-38.

Draper, H. and Hadley M. (1990). Malondialdehyde determination as index of lipid peroxidation. Methods Enzymol., 186: 421-431 .

Hissin, P.L. and Hiff R. (1976).A fluorometric method for determination of oxidized and reduced glutathione in tissues.Anal.Biochem, 74 (1): 214226.

Artimage, G.Y. and W.G. Berry,(1987):Statistical Methods 7th Ed. Ames, Iowa State University Press, 39-63.

Bancroft, J.D.; Stevens ,A .\& Turner, D.R.(1996):Theory and practice of Histological technique. 4th Ed . New York, Churchill,Livingstone. New York, London, San Francisco, Tokyo

Castelli, T. and Y. Levitar, (1977):Atherogenic ,index Curr Presc. pp: 39.

Chapman, D.G; Gastilla, R and Campbell, T.A (1950): Evaluation of protein in food, I. A. Method for the determination of protein efficiency ratio. Can. J. Biochem. Physio. I (37) 679-686

David,H and Bucolo, G (1973): Quantitative determination of serum triglycerides by the use of enzymes, Clin- Chem 1973 Vol 19 (476-482)

Lee, $R$ and Nieman, D (1996): Nutritional assessment. 2nd Ed. Mosby,Missouri, USA

NRC "National Researsh Counil" (1995):Nutrient requirement of laboratory. Fourth reviser edition .pp:29-30

Tietz, N. W (1976) :Fundamentals of clinical chemistry

Young ,D.S.(2001): Effect of disease on clinical lap . test,4th AACC press.. 
- Nutraceutical effects of Moringa oleifera, leaves, seed and extract on side effects of Isoproterenol

التأثير الغذائي والعلاجي لأوراق وبذور وهستخلص المورينجا علي الآثار الجانبية

\title{
لمركب ايزوبروتيرينول المسبب لاعتلال عضلة القلب في ذكور الفئران
}

أهداب عبدهمحمد المعداوئن

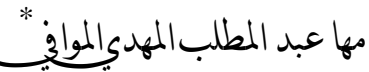

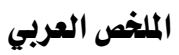

تهدف الدراسة إلى تقيهم تأثير مسحوق أوراق وبـذوروالمستخلص المائي لنبـات المورينجـا علدي

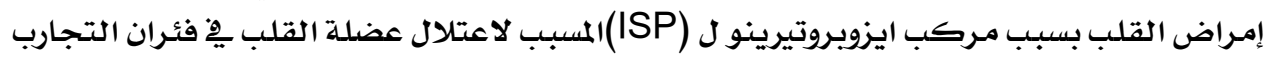

اجري الدراسة على أريعون من ذكور الفئران البيضاء المتراوح أوزنهم

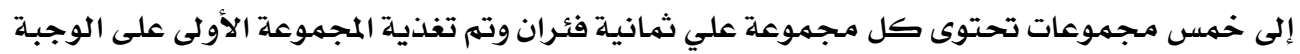

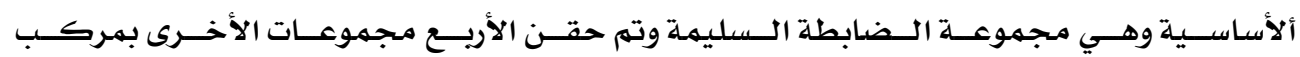

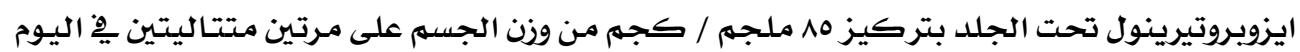

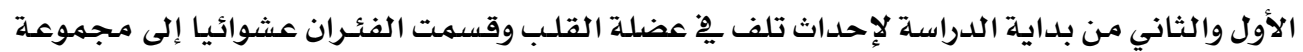

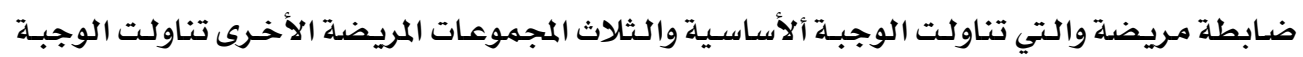

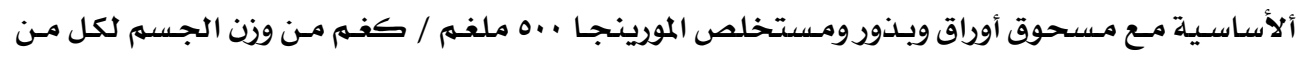

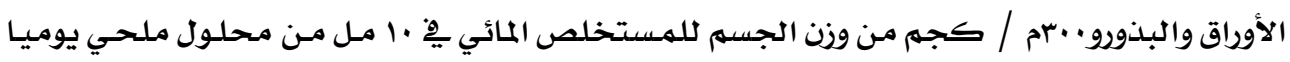

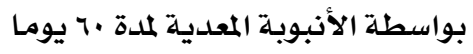

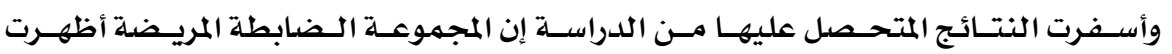

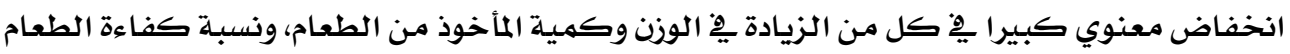

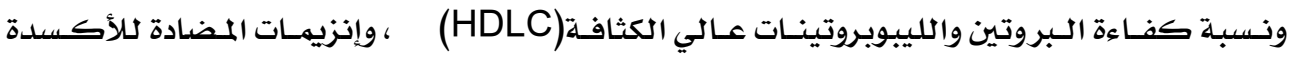

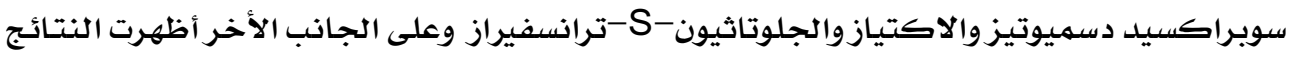

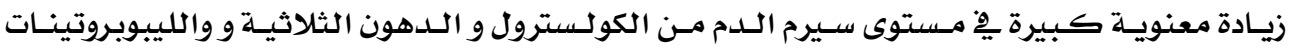

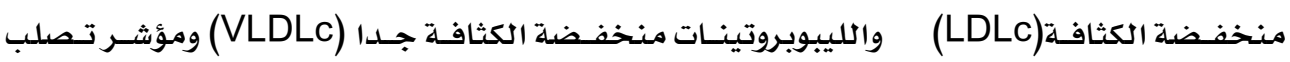

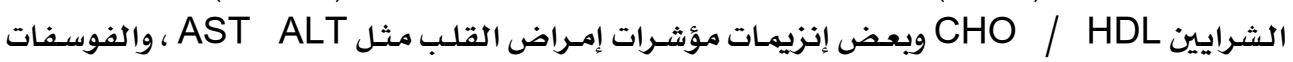

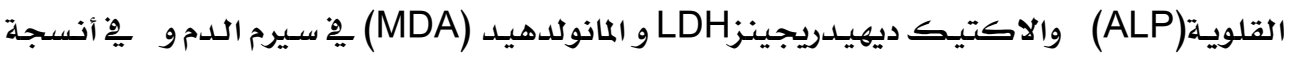

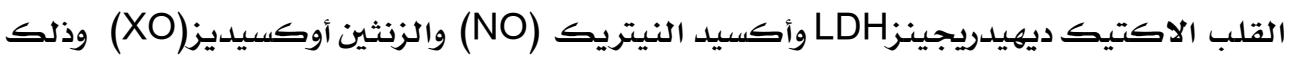

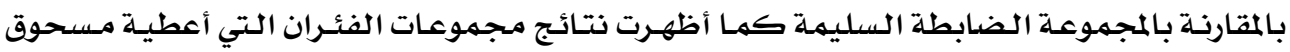

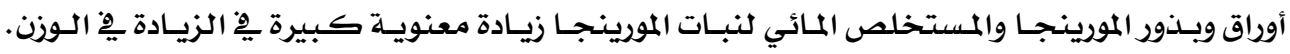

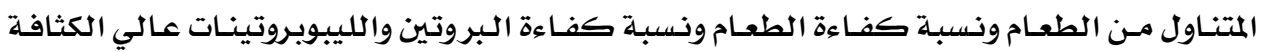

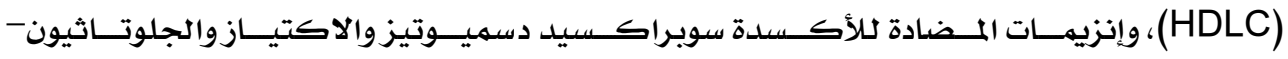

قسهم التغذية وعلوم الأطعمة ، كلية التصاميهم والاقتصاد المنزلي ، جامعة القصيم، المملكة العربية السعودية قسم الاقتصاد المنزلي كلية التربية النوعية جامعة الزقازيق مصر 


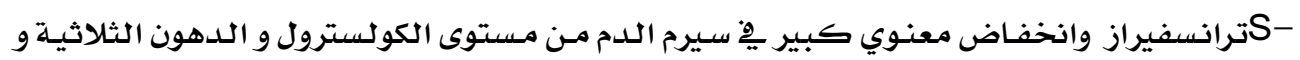

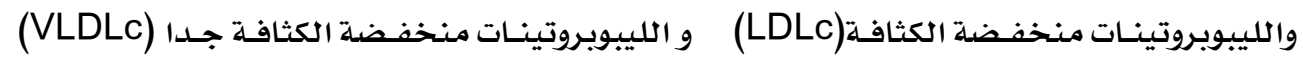

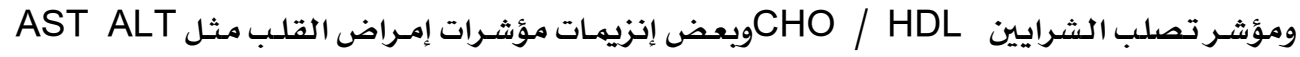

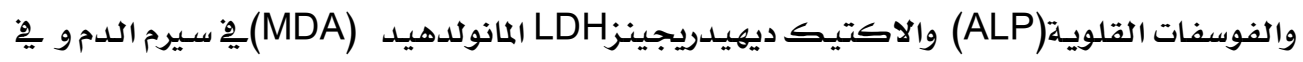

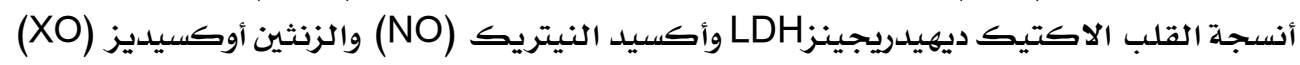

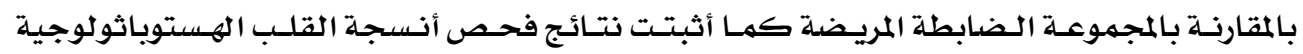

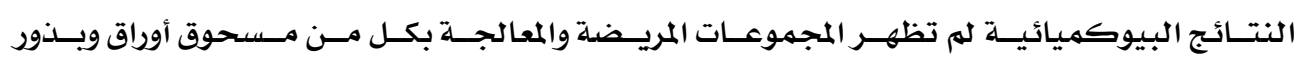

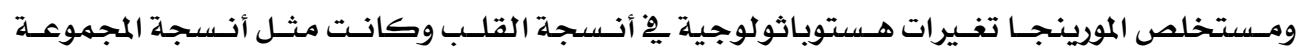

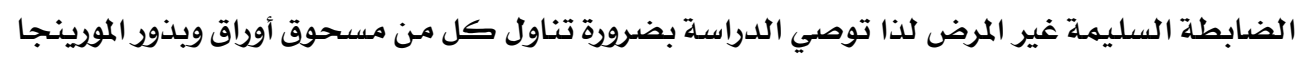

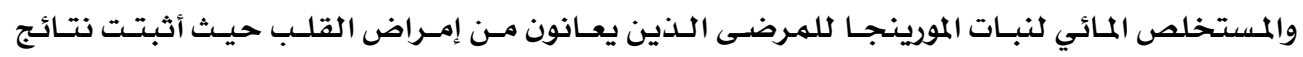

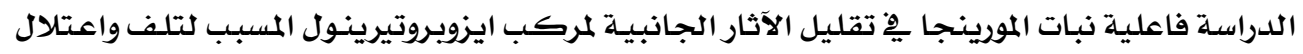

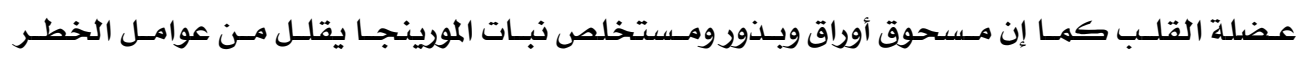

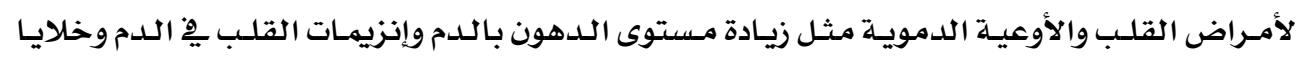
القلب المرضيه

الكلمـات المفتاحيـة : أوراق -بـذور- مستخلص - المورينـــا - ايزوبروتيرينـول - الفئـران

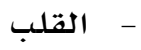

